\title{
Learning Model of Attention, Relevance, Confidence, Satisfaction (ARCS) Supported by Video Tutorial to Improve the Students' Learning Motivation in Vocational High School
}

\author{
Sigit Wahyudi ${ }^{1}$, Soetarno Joyoatmojo ${ }^{1}$, Hery Sawiji ${ }^{1}$ \\ ${ }^{1}$ Master's Degree Program in Economics Education, Universitas Sebelas Maret, Surakarta, \\ Indonesia, \\ e-mail: sheget120492@gmail.com
}

\begin{abstract}
This research is based on the low motivation of learners in Vocational High School. Students are not common to play an active role in learning so that it makes them feel bored. Therefore, the teacher tries to use ARCS supported with video tutorial as a learning medium in order to create an interesting and fun learning atmosphere. The purpose of this article is to find out whether using ARCS supported with video tutorial can improve the students' learning motivation of Vocational High School. The writing method of this article is a review of relevant research journal literature. Conventional learning model causes the students are unmotivated and lazy to learn. Thus, it needs new learning model that is ARCS supported with video tutorial. The ARCS syntax combines the students' liveliness with scientific approach and materials that are easy understanding and interesting, then it is supported with video tutorial that make the students' attention in learning increase. ARCS learning is supported with video tutorial will make the learning directed and arranged regularly and interesting for the students. In the context of learning, it requires motivation support to improve the students' learning outcomes. Through ARCS learning supported with video tutorial in Vocational High School, the students are able to be understand the relation between one contexts with others so that the students' learning outcomes have a positive change. Besides, it can also create the confidence of students and become aware of the ability of students.
\end{abstract}

Key words: ARCS; Tutorial Video; Learning Motivation

\section{INTRODUCTION}

Along with the development of era especially in the globalization era, a high quality of human resources in various fields of science is required. Improving the quality of human resources is a prerequisite needed to achieve the development of a quality nation. One way that can be done to improve the quality of human resources is through education. Education is the key to improve the quality of human resources so that the quality of education should always be improved. Various efforts to improve the quality of education in the school become main priority, one of the efforts that can be done is to improve the quality of the learning process. Improving 
the quality of the learning process can be done by increasing the potential of the teacher as one element in the learning process. Teachers who do the learning process should be able to invite learners to follow the learning process actively. One way that can be done is by applying a model of learning that can improve the students' learning motivation and learning outcomes. Teachers are the key in achieving educational reform missions, teachers play role as central point to organize, direct, and create an atmosphere of teaching and learning activities to achieve national education goals and missions. Therefore, indirectly teachers are required to be more professional, innovative, perspective, and proactive in carrying out the task of learning.

In improving the quality of the students' learning motivation learners, it cannot be separated from the role of teachers in implementing learning in the classroom. In implementing learning in the classroom model, what the teachers used in teaching is also determine the quality of the students' learning motivation. Thus, the right model of learning are needed so that the quality of the students' learning motivation can achieve maximum results. Appropriate learning model is needed for the difficult subjects for the students in Vocational High School.

To overcome the students' difficulties in learning process, it can use ARCS learning model (Attention, Relevance, Confidence, and Satisfaction) supported with video tutorial. The ARCS learning model is developed based on expectancy value theory that contains two components, they are value of the goal to be achieved and the expectation in order to achieve the goal. Two components are then developed by Keller into four components, namely: attention, relevance, confidence, and satisfaction. ARCS learning model prioritizes the attention of the students, adjusts learning materials with the students' learning experiences, creates self-confidence in students, and gives a sense of satisfaction in students [1]. ARCS learning model will further increase the attention of students when supported with video tutorial. This is in accordance with [2], which the lesson that is audio visual will make students more motivated than just reading a textbook or if the teacher is teaching only by lecture method. Motivation conditions are very important applied in the learning and learning process so that the motivation of learners can be maintained. Results of research on the development of interactive multimedia-based ARCS model for learning of Information and Communication Technology showed the success of ARCS model in student motivation of $87.58 \%$ with very good category [3]. In the syntax, it prioritizes the attention of students and adjusts the learning materials with the students' learning experiences, it will be more interesting when it is supported with video tutorial in accordance with what the students experienced in everyday life.

Based on the background above, the problem proposed is how the influence of ARCS model supported with video tutorial on the students' motivation of Vocational High School. The purpose is to find out the effect of ARCS supported with video tutorial tutorials on the students' motivation in Vocational High School.

\section{METHOD}

The method used in this article is literature study with the aim of providing knowledge about ARCS supported video tutorial to improve the students' 
motivation. The studies that contribute to this article are from the various journals related to the discussion of ARCS models and video tutorial.

\section{DISCUSSION}

\section{Definition and Concept of ARCS (Attention, Relevance, Confidence, and Satisfaction)}

A form of problem solving approach to design aspects of motivation and learning environment in encouraging and sustaining the students' motivation is ARCS model approach (Attention, Relevance, Confidence, and Satisfaction), [4]. Molaee \& Dortaj [5] state that "the ARCS is a model for analyzing motivational categories and then designing appropriate strategies based on this analysis". ARCS is a suitable model for designing strategies in analyzing motivation. Huett, Kalinowski, Moller \& Huett [6] state that ARCS is a model for behaviour, cognitive, and affective which can show that the student's motivation is influenced through external conditions. This is in line with Winaya, Lasmawan, Dantes [7], ARCS can be used for the students to build their initial knowledge in constructing knowledge obtained by the students in understanding the concept of learning, so that ultimately can be used in solving the problems given by the teachers.

From the explanation about ARCS above, it can be concluded that ARCS is a model used by the students in solving the problems based on the way the students construct the knowledge about the concept of material given by the teacher, so that it can show the motivation of the students that come from external condition.

According to Suzuki, Nishibuchi, Yamamoto \& Keller [8], the purpose of the ARCS model is to make the instruction for students to be more interested in learning activities. The provision of interesting clues is expected to affect the motivation to learn, so that learning objectives can be achieved. This is in line with the opinion of Colakoglu \& Akdemir [9], ARCS is used to guide instructional design and teachers to develop learning in integrating into motivational design. Learning developed on the basis of ARCS can increase the students' attention during learning, develop relevance to the needs of students', create positive expectations for success and have satisfaction in success [10].

ARCS is an acronym of the student's attitude of attention, relevance, confidence, and satisfaction, which is then a component of ARCS. Some components in more detail can be explained as follows.

\section{ATTENTION}

The student's attention refers to the student's sense of curiosity in the concept [11]. There is sub component in the attention, that is the student's passion during perception, giving challenging questions or problems to be solved, and brainstorming, while according to Wena [12], there are three components of strategy to generate the student's attention in learning activities, they are:

1) Generate the perception of the student, that is by using a new thing, inappropriate, or by giving sudden stimulus changes. It causes several conflicts in the students, so that it will generate the motivation to eliminate the conflict. 
2) Cultivate desire to research, that is by stimulating the student's behavior to find information by asking problem or solving problem. The existence of questions or problems addressed to the students, it is expected the attention of students more focused on learning.

3) Use various learning elements, with variation of text formatting, presenting various images, and various colour. The existence of variations aimed at the students, the students are expected to focus more and focused on learning.

\section{RELEVANCE}

According to Keller [13], relevance relates to learning materials presented to the needs and conditions of the students. Learning materials and concepts are made in such a way to make it be familiar with the students, namely with concrete examples related to the student's work, whereas according to Wena [14], to improve relevance the needs of students, there are three strategies, namely:

1) Make familiarity and good habit, namely learning is done by using and use of concrete language and concept related to the experience of student life value, learning associated with something that has been learned before will make the students more motivated in learning.

2) Present the goal-oriented learning side, that is by presenting examples or statements related the purpose and usefulness of learning.

3) Use appropriate strategies, according to the characteristics of the students in which the teacher should understand the level of student development, learning habit, and cognitive style.

\section{CONFIDENCE}

The aspect of confidence in ARCS model according to Malik [15] is focused on building positive expectations to achieve success among students. The level of the student's confidence is closely related to the level of the student's learning motivation so that the students will feel able to complete the tasks and expectations succeed in learning. In line with the opinion of Siregar \& Hartini [16] that motivation will increase with increasing self-confidence through:

1) Increase the students' expectations to succeed by multiplying successful experiences.

2) Organize learning into smaller parts so that the students are not required to study many materials at once.

3) Make the students' self-confidence appeared with constructive statements

4) Provide constructive feedback during the learning process so that the students know the extent to which the students' understanding and learning outcomes.

\section{SATISFACTION}

Aspect of satisfaction consists of several components [17], namely:

1) Provide problems, stimulation, or examples of work showing the students that the students can solve the problem of "real world".

2) Provide rewards that are in form of verbal or symbolic rewards. 
3) Make criteria that are consistent with stated expectations and make consistent measurement standards. Thus, the students will feel satisfied and motivated in every doing or completing learning tasks.

According to Homaraon [18] the implementation of ARCS learning model supported with video tutorial can implement through the following steps below, namely:

TABLE 1. SYNTAX OF ARCS MODEL SUPPORTED VIDEO TUTORIAL

\begin{tabular}{|c|c|c|}
\hline No & Syntax & Learning Process \\
\hline 1 & Attention & Engage and focus the attention of the students \\
\hline 2 & Relevance & Convey the purpose and benefit of learning \\
\hline 3 & $\begin{array}{l}\text { Attention and } \\
\text { Relevance }\end{array}$ & Deliver learning material using video tutorial \\
\hline 4 & $\begin{array}{l}\text { Attention and } \\
\text { Relevance }\end{array}$ & Use concrete examples related with real life \\
\hline 5 & $\begin{array}{l}\text { Attention and } \\
\text { Relevance }\end{array}$ & Create groups heterogeneously \\
\hline 6 & Relevance & Give learning tutorial \\
\hline 7 & $\begin{array}{l}\text { Confidence } \\
\text { and } \\
\text { Satisfaction }\end{array}$ & $\begin{array}{l}\text { Provide opportunities for the students to participate in } \\
\text { learning }\end{array}$ \\
\hline 8 & Satisfaction & Give feedback \\
\hline 9 & Satisfaction & $\begin{array}{l}\text { Conclude any material that has been delivered at the } \\
\text { end of the lesson }\end{array}$ \\
\hline
\end{tabular}

\section{Video Tutorial Media}

Susilana and Riyana [19] suggested that the tutorial model is a computer learning where the students are conditioned to follow the learning that has been programmed by the presentation of materials and exercise of questions, while Riyana [20] states that video learning media is media that presents audio and visual that contains learning messages containing the concepts, principles, procedures, application theories to help the understanding of the students in a learning material, therefore the use of this media is very appropriate in the learning process, while to Arsyad [21] states that the media good learning generally has three main characteristics, which are fixative, manipulative and distributive. The fixative has ability is to store, preserve or reconstruct an event. The manipulative feature is characterized by its ability to transfer various events in various contexts or times in an interesting plot. The distributive features are characterized by its ability to display an event or event and can be presented repeatedly without losing the essence of the thing to be conveyed.

Riyana [22] states that video learning media is media that presents audio and visual that contains learning messages containing the concepts, principles, procedures, application theories to help the understanding of the students in a learning material, therefore the use of this media is very appropriate in the learning process. 
Video tutorial is a series of learning steps through a computer where the students are conditioned to follow learning process by presenting learning materials as guidance or additional teaching materials to a small group of students. Media of video tutorial is appropriately used because the students can understand the subjects taught in Vocational High School.

Media of video tutorial has benefits when used as a medium of learning by Nugent (2005) in Smaldino [23], the video is a suitable medium for various learning media, such as classes, small groups, even one learner. The use of video tutorial is good for teaching a wide range of practical learning. In addition, the benefit of video tutorial by Luke \& Hogarth [24], "Benefits of video tutorial as a means of helping the students transition towards more independent learning approaches". The use and benefit of video tutorial as a tool to help the students' transition towards more learning approaches.

\section{Learning Motivation}

Motivation is a supporting factor that can trigger a sense of spirit and also able to change the behavior of human to lead to things better for himself. Sardiman [25] defines motivation as the supporting force within the student that leads to learning activities, which ensures the continuity of the learning activities and which gives direction to the learning activities, so that the objectives desired by the learning subject can be achieved. Motivation is a change in a person characterized by feelings and reactions to achieve goals. Motivation can be viewed from two types, namely intrinsic motivation and extrinsic motivation. Intrinsic motivation is the desire to act that is driven from within the individual, while extrinsic motivation is the motivation of existence because of the influence from outside. The behavior that occurs is influenced by the environment.

"Motivation as a direction and magnitude of behavior, especially stated that motivation is an indicator of effort", Keller 2010 [26]. Motivation is seen as a direction and how much behavior or motivation is an indicator of effort. In line with Dimyati and Mudjiono [27] motivation is an impulse that arises from within a person and can move the individual to meet individual expectations. In learning activities, business indicators are reflected in the involvement of students on the various tasks performed as effectively as possible and will affect the motivation of learners [28].

Bakar [29]; Dimyati and Mudjiono [30] describe that motivation is an encouragement that arises from within an individual and can move the individual to meet individual expectations. In the learning activities, the business indicators are reflected in the involvement of students on the various tasks performed as effectively as possible and will have an effect on the learning motivation of learners [31] [32].

Learning motivation is a process that encourages learning, direction, and persistence of behavior. That is, motivated behavior is a behavior that is full of energy and directed [33]. Thus, the role of motivation for students in learning is very important. Motivation can improve, strengthen and direct the learning process, so that the effectiveness in learning will be obtained. There are two factor of motivation [34] [35] [36] [37], namely intrinsic and extrinsic factors. Intrinsic factor is motivation that affects the students with their awareness to learn, have curiosity, and have tendency to choose challenges in order to achieve scientific goals. Extrinsic factor is the external factor of the students that affects the students' interests, 
attitudes toward learning experiences such as the influence of teachers, the desire to get maximum results and avoid punishment. The presence of a strong motivation in doing every activity, especially learning for the students, it will make the students' learning goals achieved.

\section{ARCS Model Supported with Video Tutorial to Improve the Students' Learning Motivation of Vocational High School}

According to Hermann [38], learning is required motivational support in every learning time. This support can be realized with the ARCS supported by instrumental design, this teaching strategy will improve the suitability of a controlled learning environment.

Marie [39] states that although the ARCS model is over 20 years old now but the usefulness and function remain good. The ARCS model can be used not only to design a motivating curriculum that is illustrated in the students' convenience but can also be used for basic determinations on the perception of motivating students.

Research conducted by Irwin, Ball and Desbrow [40] concludes that the use of video tutorial media at Griffith University Australia students make the students more enthusiastic in learning because video tutorial media can facilitate the students in learning activities. In addition, the use of video tutorial media can make learning more active and collaborative because the students are more active in following the lectures.

Based on the explanation above, it can be concluded that the ARCS model is used as an alternative in learning to overcome the lack of motivation in the students. This ARCS model can improve the spirit of the students in studying subjects in Vocational High School. The ARCS model has 4 stages: Attention, Relevance, Confidence, and Satisfaction. In this case, learning media is needed to help the process the implementation of ARCS learning model. In determining what learning media will be used, it needs to pay attention to several things. Namely: goals, students, availability, usability, cost, technical quality, and human resource capabilities. Thus, video tutorial is the most appropriate media for learning in Vocational High School with motivational-based ARCS learning model.

\section{CONCLUSION}

Based on preliminary study and literature study on the implementation of ARCS model supported with video tutorial as one of the scientific models to improve the students' learning motivation in Vocational High School, it can be concluded that the implementation of ARCS model supported with video tutorial can improve the motivation of the students. Learning developed on the basis of ARCS supported with video tutorial can improve the students' attention in learning, develop relevance to the needs of the students, make positive expectations for success, and have satisfaction in success. 


\section{REFERENCES}

[1] Siregar, E., \& Nara, H. (2014). Bogor: Ghalia Indonesia.

[2] Ardianti. \& Yunia, N, M. (2012). Pengembangan Media Pembelajaran Interaktif Berbasis Team Assisted Individualization Untuk Mata Pelajaran Teknologi Informasi Dan Komunikasi (TIK) Dengan Pokok Bahasan Desain Grafis Pada Siswa Kelas XII SMAN 1 Sukasada. 1 (3): 219-243.

[3] Wijana, I.D.P. \& Rohmadi, M. (2014). Analisis Wacana Pragmatik Kajian Teori dan Analisis. Surakarta: Yuma Pustaka.

[4] Keller, J. M. (2010). Motivational Design for Learning and Perfomance: The ARCS Model Approach. London: Dordrecth Heidelberg.

[5] Molaee, Z \& Dortaj, F. (2015). Improving L2 Learning: An ARCS Instructional- Motivational Approach.. Procedia: Social and Behavioral Science, 171, 1214-1222.

[6] Huett, J. B., Kalinowski, K. E., Moller, L., \& Huett, K. C. (2008). Improving the Motivation and Retention of Online Students Through the Use of ARCS- Based E-Mails. Journal of Distance Education, 22, 159-176.

[7] Winaya, I. M. A., Lasmawan, W., \& Dantes, N. (2013). Pengaruh Model ARCS Terhadap Hasil Belajar Ditinjau dari Motivasi Belajar Siswa Pada Pembelajaran IPS di Kelas IV SD Chis Denpasar. Program Studi Pendidikan Dasar: e-Journal Program Pascasarjana Universitas Pendidikan Ganesha, 3.

[8] Suzuki, K., Nishibuchi, A., Yamamoto, M., \& Keller, J.M. (2004). Development and Evaluation of Website to Check Instructional Design Based on the ARCS Motivation Model. Ministry of Education, Culture, Sport, Science and Technology: Grants-in-Aid for Scientific Research, 2 1-7.

[9] Colakoglu, O.M \& Akdemir, O. (2010). Motivational Measure Of The Instruction Compared: Instruction Based On The ARCS Motivation Theory V.S. Traditional Instruction in Blended Courses. Turkish Online Journal of Distance Education-TODJOE, 11 (2), 73-89.

[10] Malik, S. (2014). Effectiveness Of ARCS Model Of M otivational Design To Overcome Non Completion Rate Of Students In Distance Education. Turkish Online Journal of Distance Education-TODJOE, 15 (2). 194-200.

[11] Malik, S. (2014). Effectiveness Of ARCS Model Of M otivational Design To Overcome Non Completion Rate Of Students In Distance Education. Turkish Online Journal of Distance Education-TODJOE, 15 (2). 194-200.

[12] Wena, M. (2013). Strategi Pembelajaran Inovatif Kontemporer. Jakarta: Bumi Aksara.

[13] Keller, J. M. (2010). Motivational Design for Learning and Perfomance: The ARCS Model Approach. London: Dordrecth Heidelberg.

[14] Wena, M. (2013). Strategi Pembelajaran Inovatif Kontemporer. Jakarta: Bumi Aksara.

[15] Malik, S. (2014). Effectiveness Of ARCS Model Of M otivational Design To Overcome Non Completion Rate Of Students In Distance Education. Turkish Online Journal of Distance Education-TODJOE, 15 (2). 194-200.

[16] Siregar, E., \& Nara, H. (2014). Bogor: Ghalia Indonesia

[17] Keller, J. M. (2010). Motivational Design for Learning and Perfomance: The ARCS Model Approach. London: Dordrecth Heidelberg.

[18] Hamoraon. (2010). Pembelajaran Inovatif Model ARCS Keller. http://learningtheori.wordpress.com/2010/03/08/model-arcs-keller.

[19] Susilana, R., Riyana. C. (2008). Media Pembelajaran. Bandung: CV Wacana Prima.

[20] Riyana, C. (2007). Pedoman Pengembangan Multimedia Interaktif. Bandung: program P3AI Universitas Pendidikan Indonesia.

[21] Arsyad. A. (2015). Media Pembelajaran. Jakarta: Raja Grafindo Persada.

[22] Riyana, C. (2007). Pedoman Pengembangan Multimedia Interaktif. Bandung: program P3AI Universitas Pendidikan Indonesia.

[23] Smaldino, S. E., Lowthwer, D. L., dan Russell, J. D. (2008). Instructional Technology and Media For Learning. Upper Saddle River: Pearson Education Inc.

[24] Luke, B dan Hogarth, K. (2011). Developing and Enchancing Independent Learning SkillsUsing Video Tutorials As a Means of Helping Students Help Themselves. Accounting Research Journal, 24 (3) 290-310. 
[25] Sardiman. (2011). Interaksi \& Motivasi belajar Mengajar. Jakarta: PT Raja Grafindo Persada.

[26] Kutu, H. \& Sozbilir, M. (2011). Adaption of Instructional Materials Motivation Survey to Turkey: A Validity and Reliability Study. Necatibey Faculty of Education Electronic: Journal of Science and Mathematics Education, 5 (1) 292-312.

[27] Dimyati \& Mudjiono. (2013). Belajar \& Pembelajaran. Jakarta: P.T Rineka Cipta.

[28] Gomez, E. A., Wu, D., \& Passerini, K. (2010). Computer-Supported Team-Based Learning: The Impact of Motivation, Enjoyment, and Team Contribution on Learning Outcomes. Computer \& Education, 55, 378-390.

[29] Bakar, R. (2014). The Effect Of Learning Motivation On Studen's Productive Competencies In Vocational High Schlool, West Sumatra. International Journal of Asian Social Science, 4(6): 722-732.

[30] Dimyati \& Mudjiono. (2013). Belajar \& Pembelajaran. Jakarta: P.T Rineka Cipta.

[31] Chang, C., Chang, C, K., \& Shih, J.L. (2016). Motivational Strategies in Mobile InquiryBased Languange Learning Setting. Elsevier: System, 59, 100-115.

[32] Gomez, E. A., Wu, D., \& Passerini, K. (2010). Computer-Supported Team-Based Learning: The Impact of Motivation, Enjoyment, and Team Contribution on Learning Outcomes. Computer \& Education, 55, 378-390.

[33] Suprijono, A. (2009). Cooperative Learning Teori dan Aplikasi PAIKEM. Yogyakarta: Pustaka Belajar.

[34] Carenys, J., Moya, S., \& Perramon, J. (2016). Is It Worth It to Consider Videogames in Accounting Education? A Comparison of Simulation and A Videogames in Attributes, Motivation, and Learning Outcome. Spanish Accounting Review. 49 1-13.

[35] Chang, C., Chang, C, K., \& Shih, J.L. (2016). Motivational Strategies in Mobile InquiryBased Languange Learning Setting. Elsevier: System, 59, 100-115

[36] Gomez, E. A., Wu, D., \& Passerini, K. (2010). Computer-Supported Team-Based Learning: The Impact of Motivation, Enjoyment, and Team Contribution on Learning Outcomes. Computer \& Education, 55, 378-390.

[37] Harandi, S. R. (2015). Effects of e-Learning on Students' motivation. Procedia: Social and Behavioral, 181, 423-430.

[38] Herman, A., Wiesner, C. (2004). Journal of Educational Multimedia and Hyprmedia. Norfolk, 13, 3-19.

[39] Marie, C. (2015). Learner Characteristics and Motivation: How to Achieve Efficient and Effective Learning. Collected Essays On Learning and Teaching, 8, 1-6.

[40] Irwin, C., Ball. L., Desbrow. B. (2012). Students' perceptions of using Facebook as an interactive learning resource at university. Australasian Journal of Educational Technology, 28(7), 1221-1232. 